\title{
Assessment of Deep Geothermal Energy Exploitation Methods: the Need for Novel Single-Well Solutions
}

\author{
Falcone, G..$^{*}$, Liu, X. ${ }^{(*, 1)}$, Okech, R.R..$^{(* *)}$, Seyidov F. ${ }^{(* *)}$, Teodoriu, C. ${ }^{(* * *)}$ \\ (*) Oil and Gas Engineering Centre, Cranfield University, MK43 OAL, Cranfield, UK \\ (**) Diageo, Kenya \\ (**) Clausthal University of Technology, Clausthal, Germany \\ (***) The University of Oklahoma, Norman, Oklahoma
}

\begin{abstract}
Geothermal energy is a constant and independent form of renewable energy and plays a key role towards the world's future energy balance. In particular, deep geothermal resources are largely available across continents and can help countries become less dependent on energy imports and build a broader base in their future energy mix.

However, despite its significant potential, the total contribution of the geothermal sector to global power generation remains relatively small. The International Energy Agency has recommended devising plans to address technology-specific challenges to achieve faster growth and improving policies tackling pre-development risks for geothermal energy. Reaching considerable depths is a requirement to exploit deep geothermal resources, but experience gained to date from the implementation of complex, engineered deep geothermal projects has unveiled technical and economic challenges, lower-thanexpected performance and poor public image. There is therefore an urgent need for alternative, more sustainable well designs.

This paper critically assesses conventional and unconventional deep geothermal well concepts, focusing on the basic Borehole Heat Exchanger (BHE) concept. The discussions are supported by numerical simulations of a BHE design that includes heat conductive fillers to enhance the heat exchange with the surrounding formation, while avoiding direct fluid interaction with the latter.
\end{abstract}

Keywords: Deep Geothermal Energy; Geothermal Potential; Deep Borehole Heat Exchangers.

\section{Introduction}

One of the most abundant energy sources exists in renewables is geothermal energy, which is considered by many to be a constant and independent supply. Geothermal energy already plays a vital role in some countries, such as Iceland (27\% of power) and El Salvador (26\% of power) [1,2]. Deep geothermal resources are largely available across continents and can help countries become less dependent on energy imports and build a broader base in their future energy mix. Generally, however, the total contribution of the geothermal sector to global power generation remains relatively small $(0.3 \%)[1,2]$. According to the International Energy Agency (IEA) [3], geothermal electricity production has not experienced significant growth between 1990 and 2016, with an average annual rate of $2.3 \%$, from $28.6 \mathrm{TWh}$ to $51.8 \mathrm{TWh}$. It is believed that continued low fossil fuel prices, together with high drilling costs and high project development risk, have created unfavourable conditions for geothermal power development [4] [5]. Based on the IEA's $2^{\circ} \mathrm{C}$ Scenario (2DS), which lays out an energy system deployment pathway and an emissions trajectory consistent with at least a $50 \%$ chance of limiting the average global temperature increase to $2{ }^{\circ} \mathrm{C}$ (reducing $\mathrm{CO}_{2}$ emissions by almost $60 \%$ by 2050, compared with 2013), geothermal is not on track (see Fig.1) [5]. Hence, for 2017, the IEA recommended devising plans to address technology-specific challenges to achieve faster growth and improving policies tackling pre-development risks for geothermal energy.

\footnotetext{
${ }^{1}$ Corresponding author, E-mail: Xiaolei.Liu@cranfield.ac.uk (X. Liu), Tel: +44-1234-75-5282.
} 


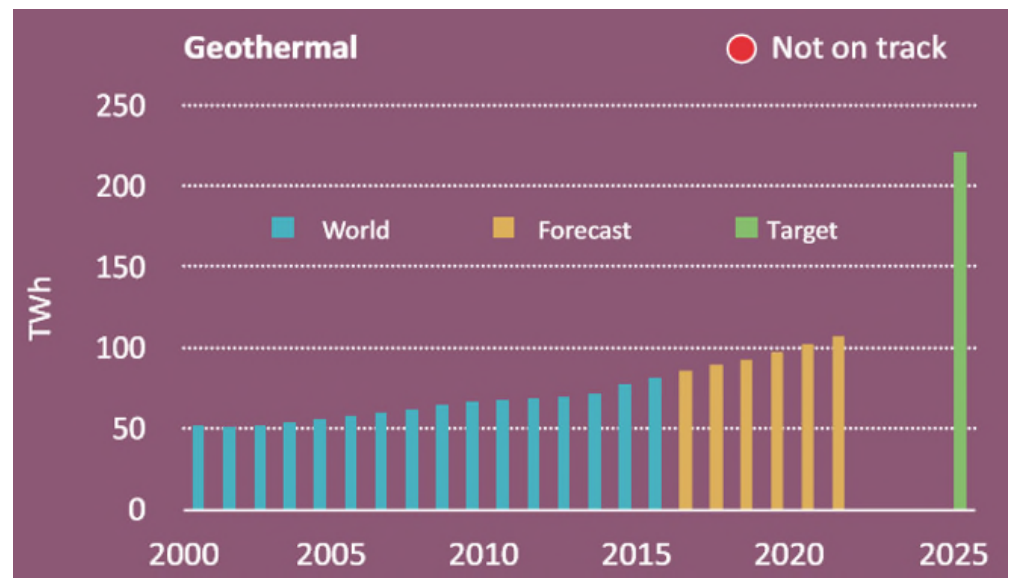

Fig. 1. Geothermal technologies not on track to reach their 2DS targets [5].

In geothermal energy exploitation, depending on the temperature of the geothermal resources, the produced fluids can be used for heating (and cooling) and/or power generation. Depth is a necessity to attain sufficiently high temperatures for largescale heating and cooling projects and for power generation. Accessing such deep targets poses the challenges of increased capital and operational costs and higher development risks. To date, the implementation of Enhanced (or Engineered) Geothermal Systems (EGS), following the original Hot Dry Rocks (HDR) two-well or doublet model, has been met with technical and economic challenges, lower-than-expected performance and limited public acceptance, as they typically require the "engineering" of the reservoir by artificial stimulation to create the necessary heat exchange in the subsurface. A recent study [6] reviewed 18 significant EGS sites and technologies that have been applied in the European Union, Japan, South Korea, Australia and the USA, concluding that site characteristics remain a key factor in determining whether an EGS development can be successful.

It has also been pointed out that, by 2050, over half the projected increase in geothermal power should come from EGS, but such technology is still in the demonstration stage [7]. In fact, there remains uncertainty regarding the specific technology requirements for EGS reservoir creation, with operational experience to date being measured in months rather than years in the majority of the cases [8]. EGS projects so far have targeted site specific characteristics, such as pre-existing faults, requiring stimulation of those pre-existing fault systems to try and achieve commercial flow rates. Stimulation of pre-existing fault systems, however, runs the risk of associated seismic events. The city of Pohang in South Korea, for example, has recently experienced a magnitude 5.5 seismic event, which may have been related to hydraulic stimulation activities at the nearby geothermal project [9].

There is therefore an urgent need for not only continued research into EGS technology, but also for dedicated research into alternative, more sustainable well designs that can make a deep geothermal development as independent as possible from site specific reservoir characteristics, while aiming at the financial viability of the solutions proposed. There is also a need to move away from EGS/hydraulic stimulation and find more stable alternatives.

\subsection{Overview of Deep Geothermal Environments}

A comprehensive review of deep geothermal systems and their classification was given by Breede et al. [11]. Deep geothermal systems are commonly divided into hydrothermal and petrothermal. The first category includes geothermal reservoirs that provide a heat source, a natural reservoir with high enough permeability and a water recharge. The second category comprises geothermal systems where a natural heat source exists, but the underground heat exchanger must be created artificially and water must be supplied for water circulation within. Hydrothermal systems are dominant in terms of number of occurrences worldwide and megawatts of electrical power generated. 
More recently, the definition of EGS was introduced for deep geothermal systems that require technical enhancement, such as hydraulic stimulation to create an artificial reservoir, or the supply of water, when not naturally present in sufficient amounts in the underground. This definition relates to petrothermal systems, but hydrothermal systems may also require permeability enhancement or artificial water supply to increase system productivity [10]. Fig. 2 presents an overview of reservoir/bottomhole temperature versus depth for EGS projects worldwide. Compared to Europe, the average EGS reservoir/bottomhole temperatures in America, Australia and Asia are higher, although well depths are comparable. Based on data available in the public domain, the installed electrical and thermal capacity of worldwide EGS projects are summarized in Fig. 3. Even though the variation of production scale corresponds to significant capacity differences among the projects, the overall capacity potential of deep geothermal systems is apparent.

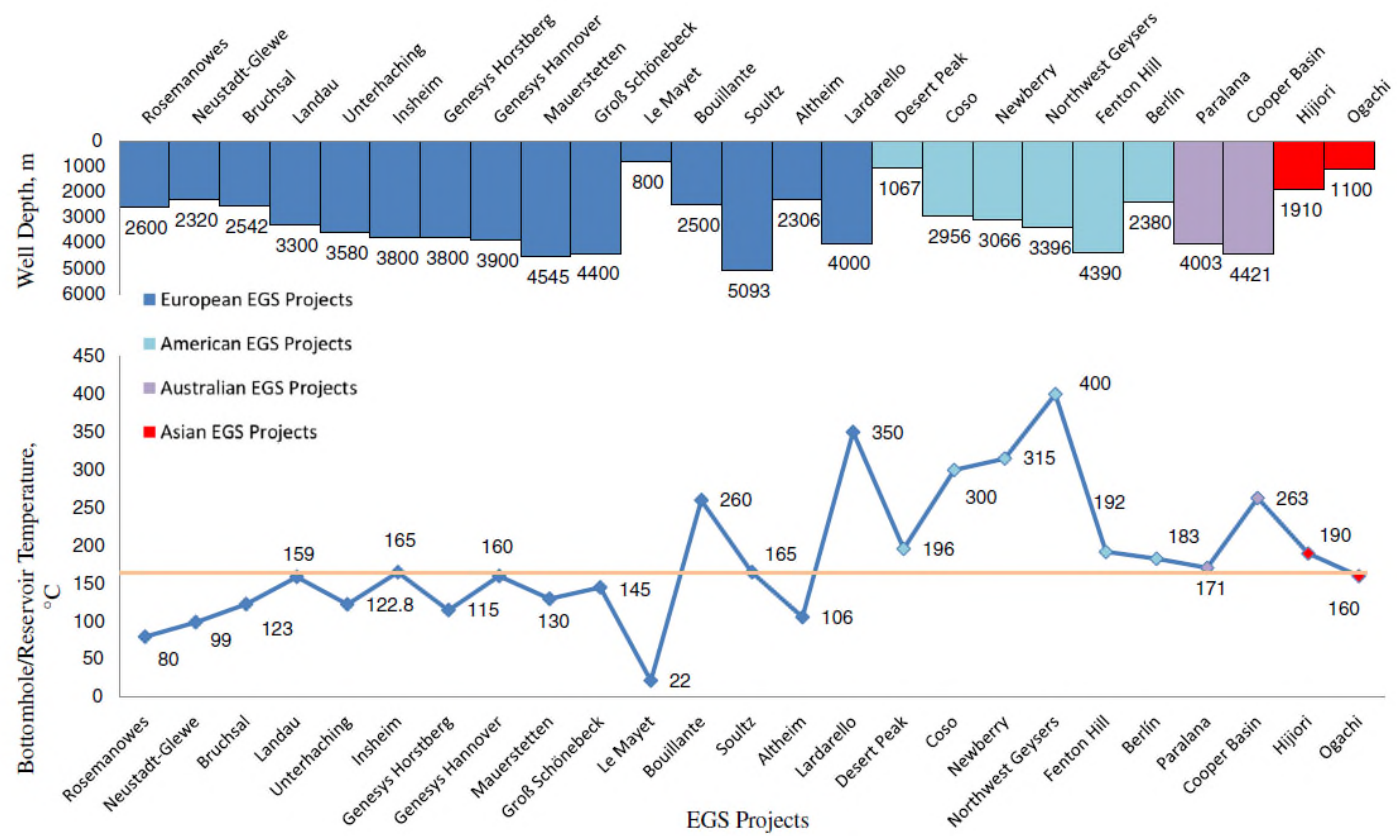

Fig. 2. Worldwide EGS projects' reservoir/bottomhole temperature vs. depth as of 2013 [11].

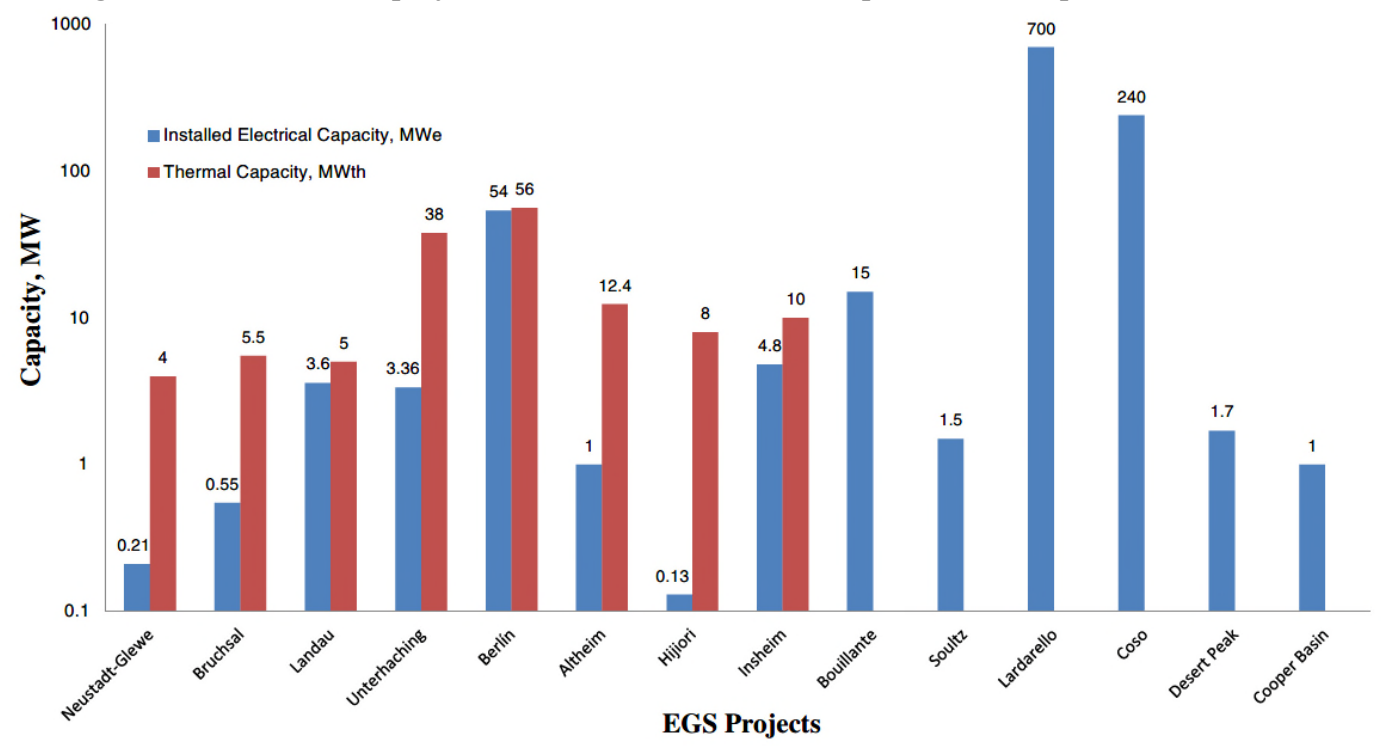

Fig. 3. Installed electrical and thermal capacity of worldwide EGS projects as of 2013 [11].

The recently developed definition of hot sedimentary aquifer (HSA) was introduced to describe systems having a heat source that is conduction-dominated, rather than convection-dominated. Breede et al. [10] presented a database of petrothermal 
and HSA projects worldwide, grouping them by 'deep geothermal' parameters, such as depth, formation type, porosity, permeability, downhole temperature, circulation rates and stimulation method, if any. The inclusion of HSA among deep geothermal systems adds to the overall potential of these resources.

In addition, the feasibility of employing supercritical $\mathrm{CO}_{2}$ as the working fluid to harness geothermal energy has been broadly investigated, based on the original concept of EGS in recent years. Compared to brine/water, $\mathrm{CO}_{2}$ has lower kinematic viscosity and higher thermal expansibility, allowing more effective heat extraction from the subsurface. [12]

In what follows, a review of exploitation methods specifically proposed to untap the complex deep geothermal resources is presented.

\section{Unconventional Deep Geothermal Exploitation Methods}

Various methods for deep geothermal energy exploitation have been proposed in literature, some of which have been prompted by the need to design methods suitable to situations where the heat is available, but not the permeability and/or the porosity of the formation.

\subsection{Hot Dry Rock (HDR)}

Original HDR concept [13] and its derivations [14] are based on the artificial creation of hydraulic connectivity between injection and production wells (see Fig. 4), which is the root of the current term EGS introduced earlier. It was tested for the first time at Fenton Hill by a research team from Los Alamos National Laboratories in 1977 [13]. Based on the experience at Fenton Hill, the HDR concept was subsequently implemented at Rosemanowes (UK) with the purpose of addressing largescale rock mechanics experiments [14].

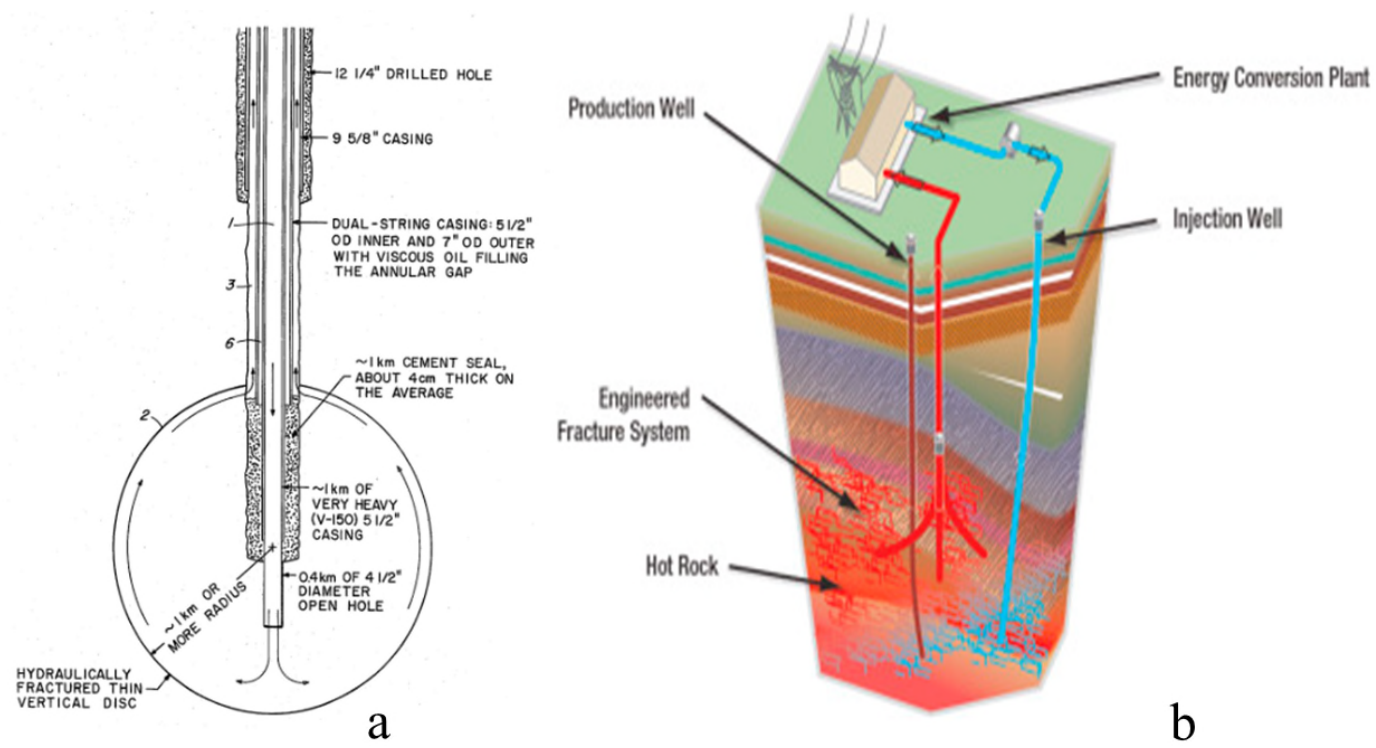

Fig. 4. The original HDR concept (a) [13] and (b) [15].

Over the years, several designs for connecting the wells' doublet have been investigated. See the work by Shiozawa and McClure [16], for example, in relation to multiple-stage hydraulic stimulation and geomechanical stress regime (Fig.5). 

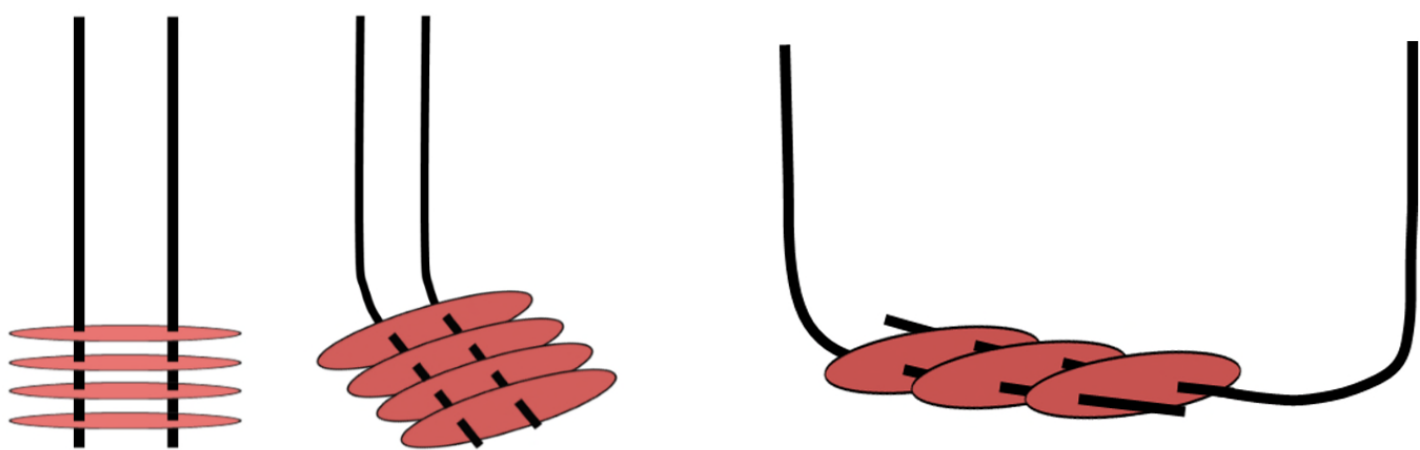

Fig. 5. Multiple stage EGS concepts. Left to right: horizontal fractures forming in a reverse faulting regime, stacked vertically; wells deviated at an angle from vertical, placed side-by-side, and connected with vertical fractures (normal or strike slip faulting regime); wells oriented toe to heel to encourage equal flow rates between stages, connected by vertical fracture stages (normal or strike-slip faulting regime). [16]

\subsection{The single-well (U-tube) concept}

In the single-well (U-tube) concept, geofluids are circulated in a U-shaped wellbore/chamber to absorb thermal energy from the underground region by direct heating. This idea was first proposed in the form of a patent by Isaakidis [17]. As can be seen in Fig. 6 a, the U-shaped wellbore has a spiral energy harnessing system with a pressurized return path. The geofluids are sent down by gravity to collect the heat from underground spiral chambers, then rise up in the return outlets to an energy conversion system on the surface. [17] Lately, GreenFire has announced that it will initiate a demonstration project based on the single-well (U-tube) concept, as presented in Fig. 6 b, which uses supercritical $\mathrm{CO}_{2}$ as the geofluids instead of water [18]. GreenFire plans to reuse an underperforming hydrothermal well at the Coso KGRA in Inyo County California for building the first field-scale pilot project to produce grid-scale geothermal energy without the consumption of water. [18]

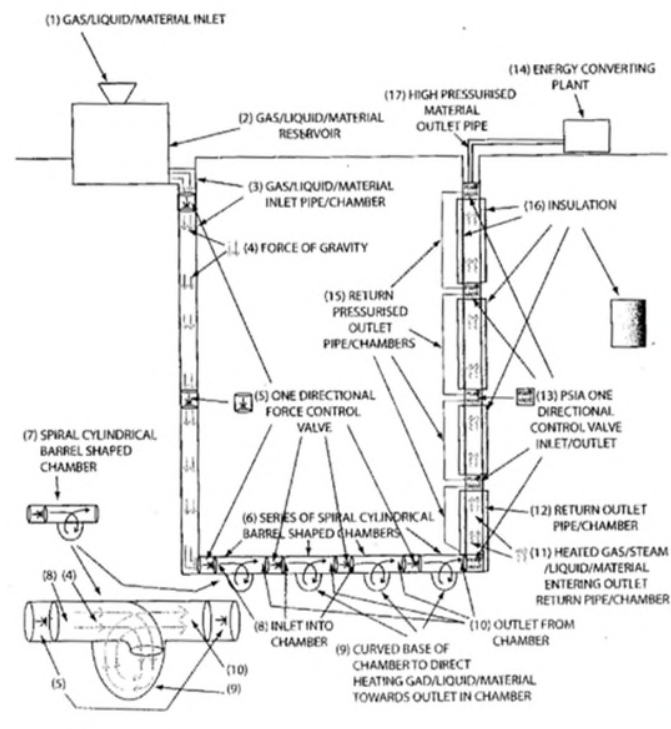

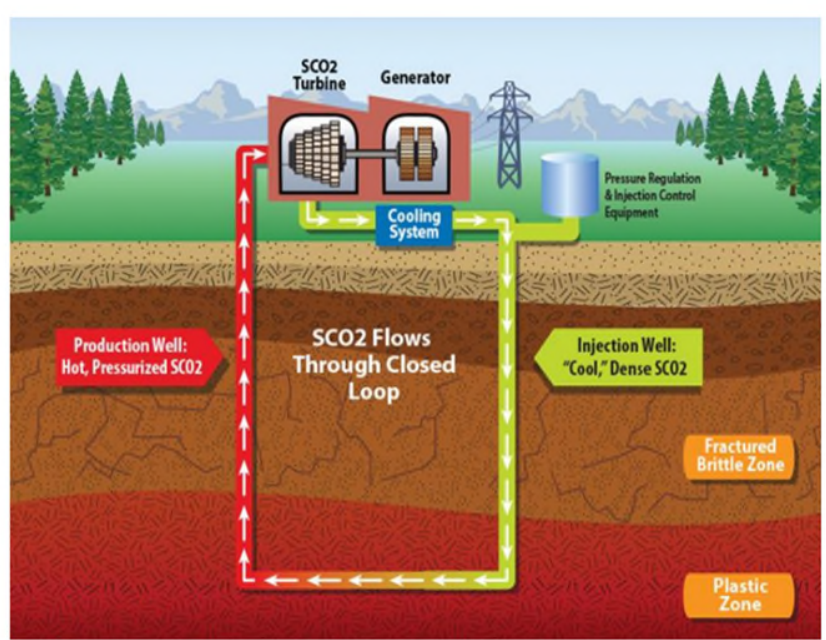

b

Fig. 6. Single-well (U-tube) concept (a [17] and b [18]).

\subsection{The single-well (open loop) concept}

Single-well concepts have the overall advantage of reducing deep geothermal costs, where only one well is needed to be drilled. The concept considers the geofluids are injected and produced through the same well, with or without natural or induced 
fractures. Meanwhile, the challenge of achieving high heat flux/thermal output remains. The single-well (open loop) concept relies on different sections of a well (casing and tubing) connecting to production layers or to injection layers, where layers are isolated from one another. To date, the GeneSys-project (see Fig. 7) is the only project worldwide that tested (with partial success, due to salt deposition issues [11]) the single-well (open loop) concept for direct use of geothermal energy. As shown in Fig. 7, the concept consists of a dual-string single borehole and a hydraulically stimulated fracture. [19]

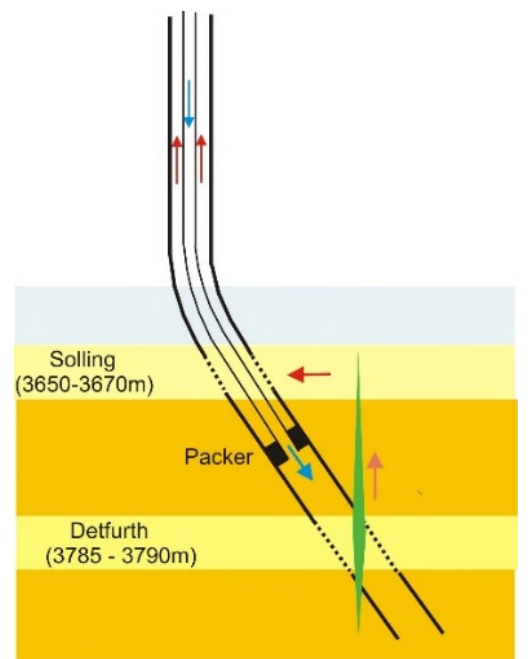

Fig. 7. The Genesys concept [19].

Another single-well (open loop) type was proposed by Gedzius and Teodoriu [20]. The concept focused on reducing drilling costs, as well as creating sustainable systems and maximizing the heat recovery. An open loop system of the single well is created together with two or more horizontal lateral boreholes, with sufficient length and diameter, consisting of a sealed casing and open bottom tubing. If there is lack of natural fissures, artificial cracks can be created via hydraulic fracturing, which is in connection to each other and to horizontal wells (see Fig. 8). [20]
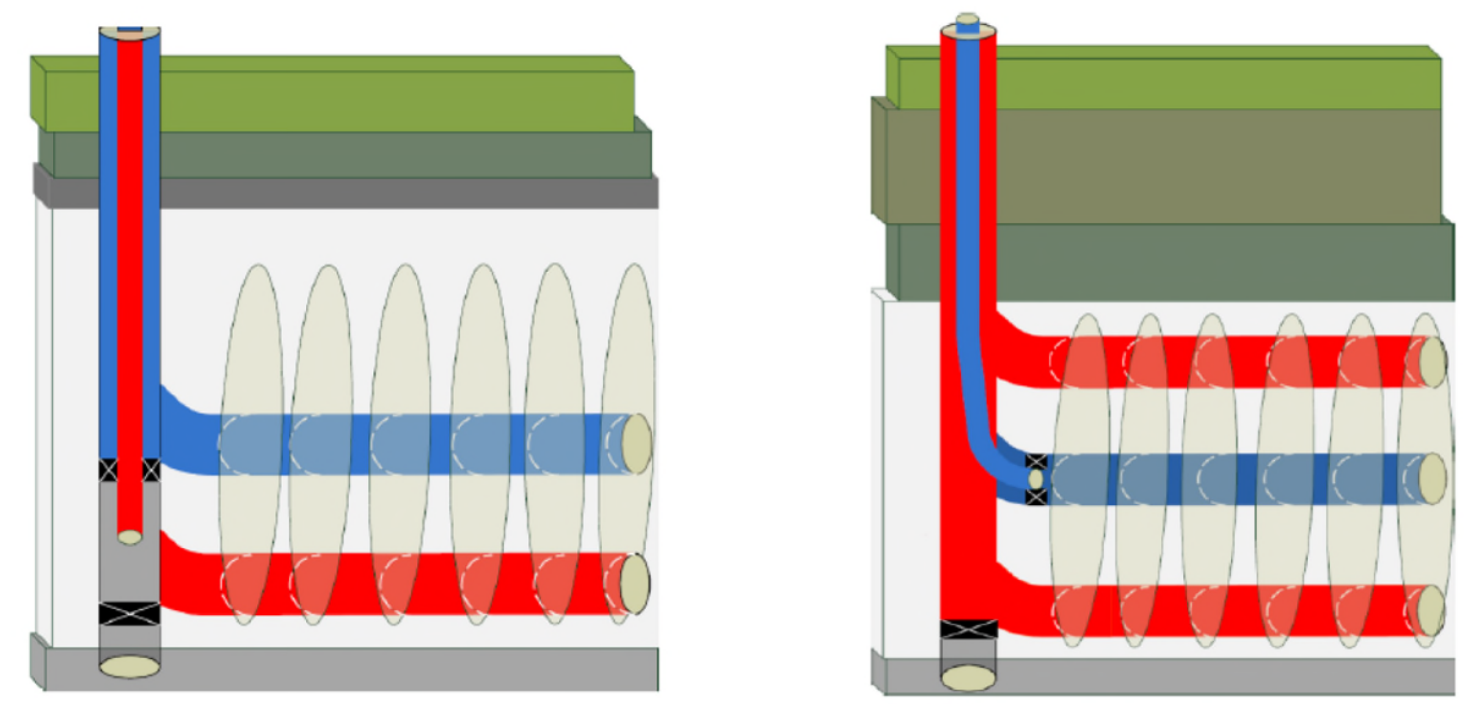

Fig. 8. Single-well (open loop) concept with multilateral branches [20].

To the authors' knowledge, this concept has not yet been implemented in the field.

\subsection{The single-well (closed loop) concept}


In the single-well (closed loop) concepts, geofluids are circulated in the borehole, where they are not in contact with the surrounding formation. It is assumed that sufficient heat can be transferred from the formation to the wellbore, despite the significantly smaller contact area compared to that achievable via fracturing. Such systems can be more attractive in terms of reduced geological/reservoir risk (no direct fluid-rock interaction) and lower cost (one well only).

Depending on the temperature, heat flux output and their sustainability over time, single-well (closed loop) systems can be used for electrical power generation, direct use/district heating or combined heat and power (CHP). Besides the technical feasibility and the presence of end customers, the economics are key to determine the overall feasibility of a deep geothermal project. As already discussed, certain concepts rely on fractures to provide a necessary contact area for pumped fluids to gain the underground heat. Those deep geothermal concepts may induce seismicity. The recorded maximum magnitudes of induced seismic events associated with the development of EGS projects worldwide are shown in Fig. 9. The potential for associated induced seismicity is perceived as an obstacle to further development of EGS systems requiring hydraulic stimulation [21]. Microseismic monitoring has therefore become an indispensable technology for public acceptance in deep geothermal projects and significant advances have been made in the development of models to quantitatively predict induced seismicity [21].

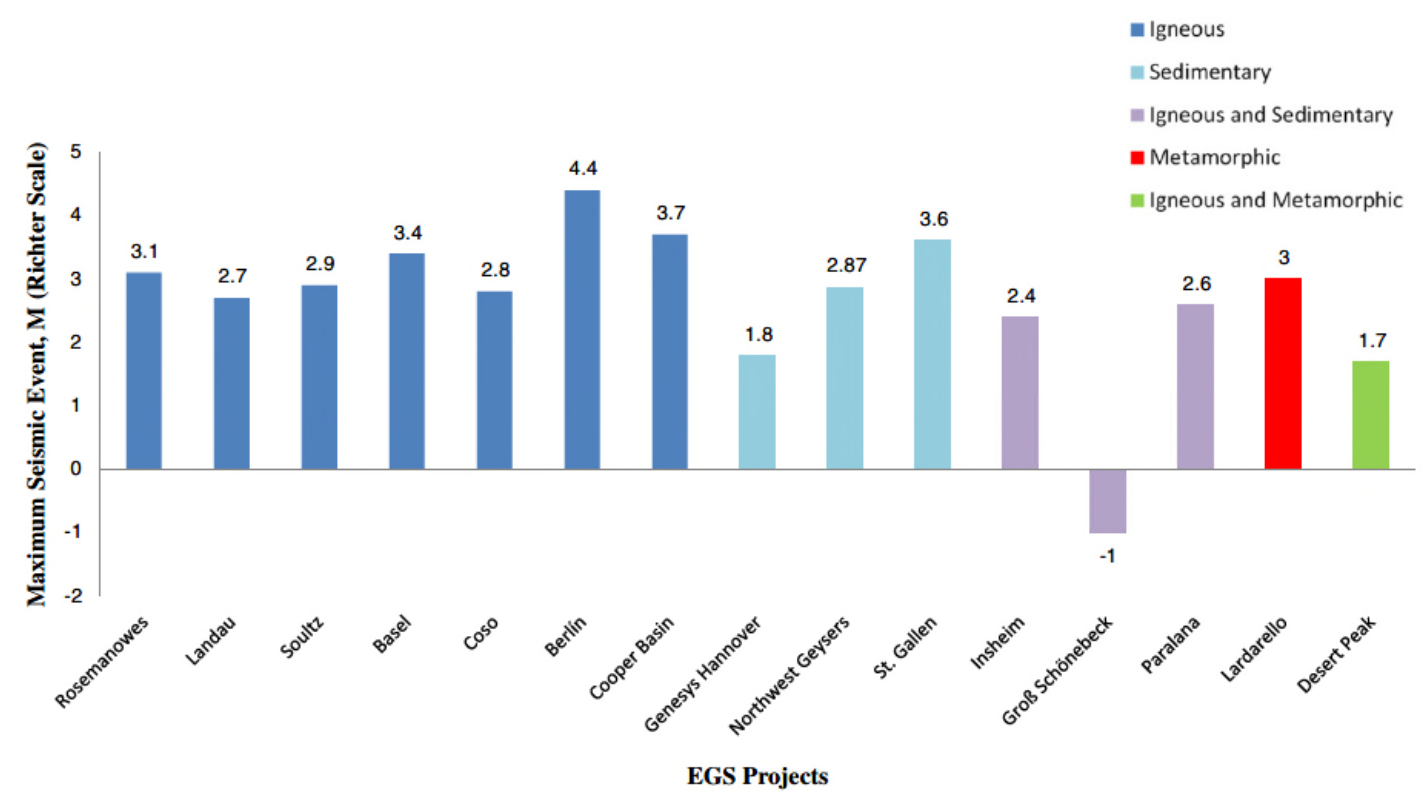

Fig. 9. Projects with published induced seismic magnitude as of 2013; note that, due to the higher accuracy of modern seismographs, the Richter scale now measures earthquakes having negative magnitudes. [11]

When hydraulic stimulation is not allowed or considered to be insufficient to lead to economic circulation rates, alternative concepts are required. The fourth and last concept, that of a single-well (closed loop), is further investigated in what follows, beginning with a presentation of existing and proposed examples of such geothermal well type.

\section{Implemented Single-well (closed loop) projects}

The single-well (closed loop) concept, also called borehole heat exchanger (BHE), can be used in deep geothermal applications, particularly when there is an opportunity to access abandoned "dry" geothermal or hydrocarbon exploratory holes. However, to date, only a handful of BHEs have been implemented worldwide (primarily in Europe) with mixed success. Some of these are described below.

\subsection{The BHE project in Weggis, Switzerland}

Since 1994, a BHE project has been operated in Weggis, Switzerland, with a bottomhole temperature of $78^{\circ} \mathrm{C}$ and a depth of $2300 \mathrm{~m}$ [22]. See the well's schematic diagram in Fig. 10. As reported by Eugster and Füglister [23], the single well delivered $220 \mathrm{MWh} / \mathrm{yr}$ (thermal) for direct heating and heat pump applications from 1995 to 2000, with an average production temperature of $40.5^{\circ} \mathrm{C}$ and an average return temperature of $33.3^{\circ} \mathrm{C}$. In 2001 , three additional multi-family dwellings were 
connected to the system. As the delivered heat supply was nearly doubled, the production temperature reduced to $37.2^{\circ} \mathrm{C}$. In addition, the upper portion $(0-1780 \mathrm{~m})$ of the inner pipe of the Weggis deep BHE is thermally well insulated (with vacuum).

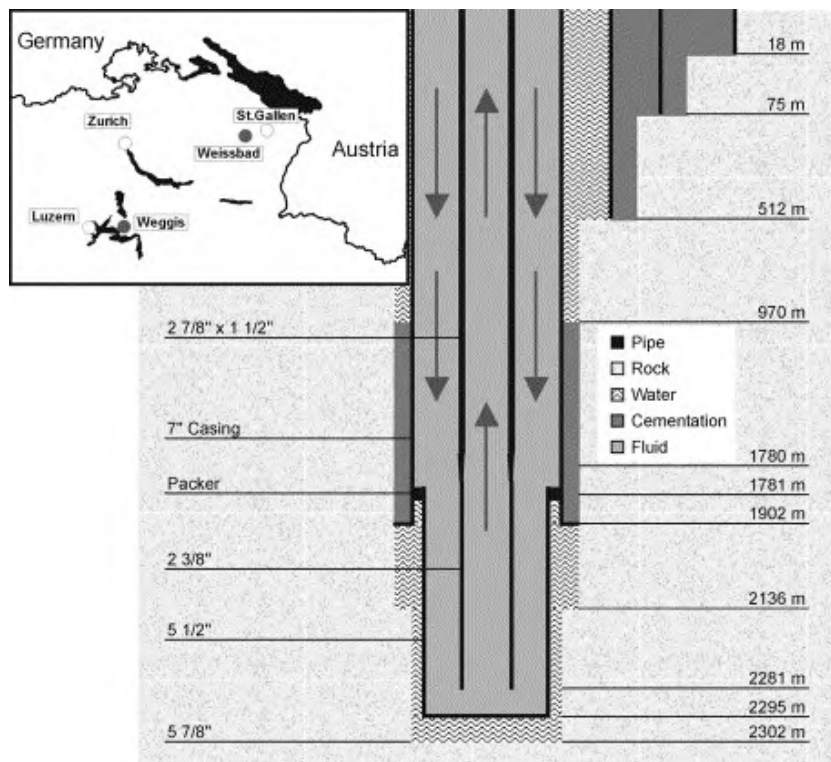

Fig. 10. Completion of the $2295 \mathrm{~m}$ deep BHE in Weggis with location of deep BHE plants in NE-Switzerland (top left). Outer casing diameter and thickness on the left margin. Black: casing; grey: cementation between pipes. [24]

\subsection{The BHE project in Weissbad, Switzerland}

A deep BHE project in Weissbad, Switzerland used an existing borehole, which was re-drilled with the aim of finding a porous/fractured aquifer and supplying an adjacent spa and hotel complex in 1993 [25,26]. As the deeper drilling encountered only tight formations, it was decided to equip the borehole with a deep BHE instead. The well was cemented down to $1213.3 \mathrm{~m}$, where met a downhole temperature of $45^{\circ} \mathrm{C}$ (see Fig. 11). It was anticipated that this design would achieve an average delivery temperature of about $15{ }^{\circ} \mathrm{C}$, but the actual operation revealed a yield of just $10.6{ }^{\circ} \mathrm{C}$ with a water circulation rate of $252 \mathrm{~m} / \mathrm{d}$. Based on numerical analysis, Kohl et al. [25] concluded that the system's poor performance was caused by the poor casingformation contact and the poor insulation of central pipes.

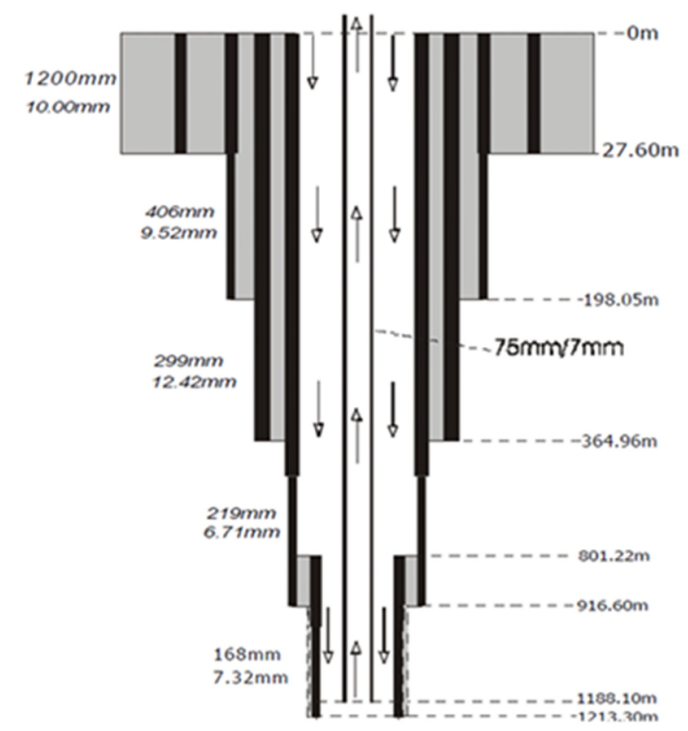

Fig. 11. Completion of the BHE in Weissbad, Switzerland; depth is given on right: outer casing diameter and thickness are given on the left; black denotes casing; grey denotes cementation between pipes [25]. 


\subsection{The SuperC project in Aachen, Germany}

A geothermal well with a depth of $2500 \mathrm{~m}$ was used to supply heating and cooling to the new "StudentService-Center SuperC" building at RWTH Aachen University, Germany (see Fig. 12). During the project, several technical issues arose with glass fiber reinforced plastic pipes, which is used as the internal tube in the cased wellbore. Then, a new type of plastic for the inner tube was invented and patented at the RWTH Aachen University, but it was unable to be deployed at depths greater than $1965 \mathrm{~m}$. As a result, a maximum temperature of $35^{\circ} \mathrm{C}$ (instead of the planned $60^{\circ} \mathrm{C}$ ) was attained at the wellhead [27]. Although the well was regarded as a success from the point of view of gathering valuable experimental data for further projects and proving the feasibility of deep drilling in an urban area (including the hammer drilling technique for the first borehole section), the project was ultimately declared a commercial failure in 2014.

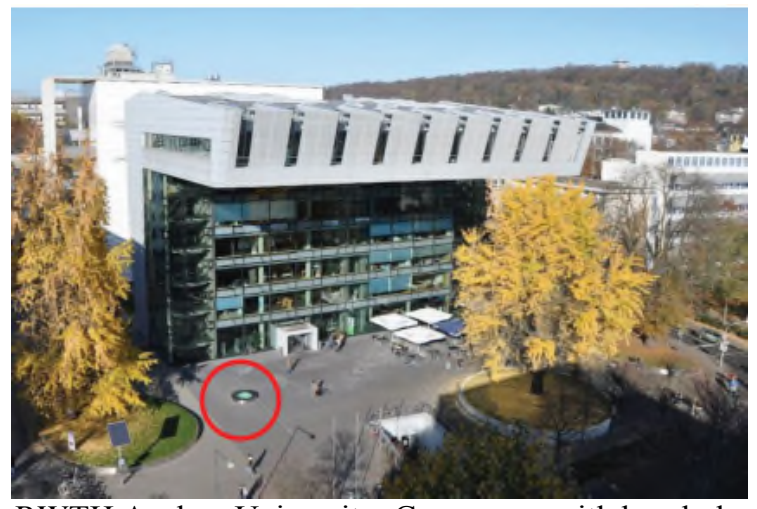

Fig. 12. The SuperC of the RWTH Aachen University, Germany g with borehole cover in the red circle [28].

\subsection{The deep geothermal single well (DGSW) technology, UK}

The DGSW concept is the application of coaxial BHE design in deep geothermal, where a single wellbore is structured, forming a centred outlet and an annular inlet (Fig. 13 a). In 2014, this technology was implemented in a field trial by reutilizing an existing well that was drilled in Cornwall during the 1980s (Fig. 13 b). Pilot tests were performed on the site to record data through a fibre optic cable along the well, which was used in the calculation of thermal performance. The field trial identified the technical feasibility of the DGSW system. Within the current wellbore configuration, the produced fluids have a delivery temperature of $69^{\circ} \mathrm{C}$, creating a peak load of $363 \mathrm{~kW}$ and an equivalent coefficient of performance (COP) of 52. [29]

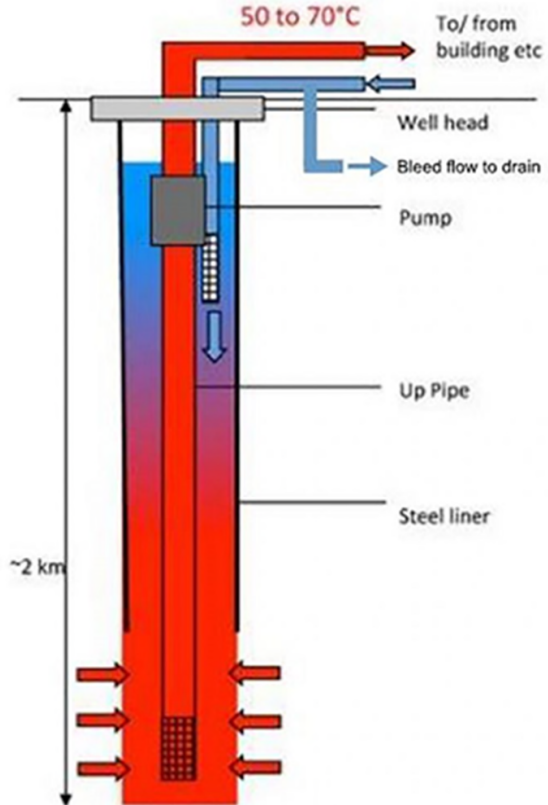

a

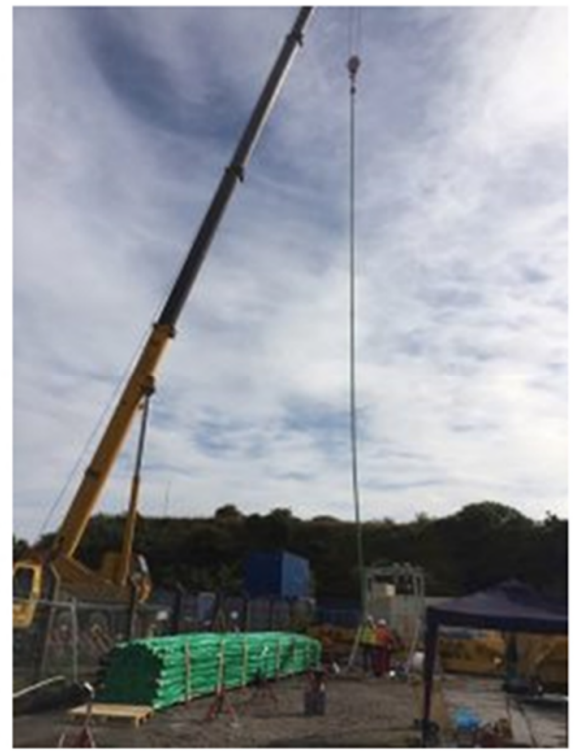

b

Fig. 13. Schematic of the DGSW concept (a) and the site of the field trial (b) [29]. 
Several projects have been planned across the UK, based on the DGSW technology. One of them will consist of a singlewell system to deliver heat to a portion of the Jubilee Pool, Penzance; it is anticipated that drilling of the well will commence in late 2017. [29]

\section{Proposed Single-well (closed loop) designs for electrical power generation}

Having discussed past application of the single-well (closed loop) concept to relatively deep geothermal energy extraction for direct use/district heating, this section will assess patented unconventional designs that aim at generating electrical power via modifications of the original BHE concept. To date, deep BHEs have been drilled to less than 2500 m, with a maximum output heating capacity range of 500-750 kWth, and only limited to heating and cooling applications. Several variations of the original deep BHE concept have been proposed and patented in the literature for electrical power production.
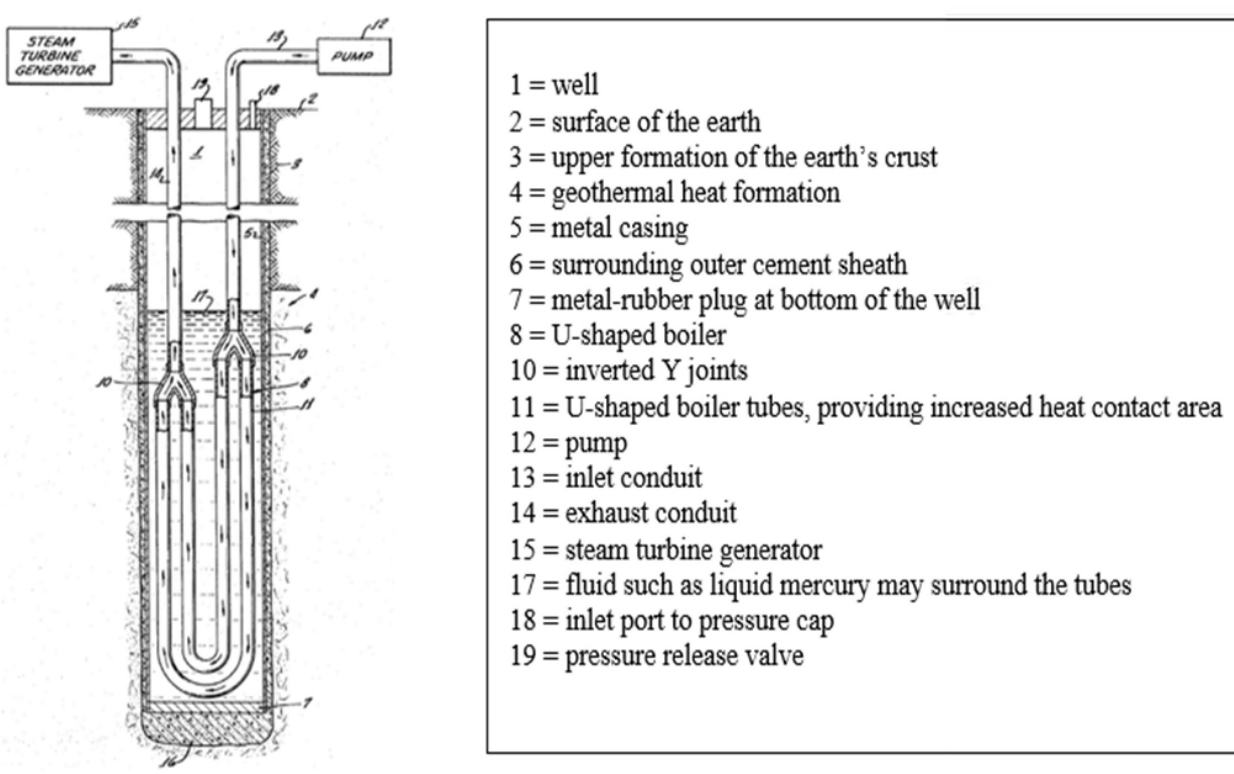

Fig. 14. Deep geothermal well concept with U-shaped boiler tubes and Y joints for steam generation [30].

Fig.14 shows the concept from Van Huisen [30], who suggested drilling a well into a deep geothermal heat formation in which to install a closed loop system of concentric U-shaped boiler tubes and inverted Y spool pieces. The sump of the well, where the tubes would sit, would be filled with superconductive materials to enhance heat transfer from surrounding formations. Boiler feedwater would be pumped downhole and converted into saturated and then superheated steam, which would be sent to a steam turbine generator for utilization.

Hunt [31] proposed to transform air into a cryogen (a substance with a temperature below $-150^{\circ} \mathrm{C}$ ) and inject this supercold liquid into a deep geothermal well via a U-tube heat exchanger that through a thermoelectric generator, forming its coldside. The air cryogen within the U-tube is vaporized by the heat within the well, so cryogenic vapor flows to the bottom of the well. The cryogenic vapor returns to the thermoelectric generator within the closed U-Tube, which delivers heat from the bottom of the well that forms its hot-side (see Fig.15 a). 

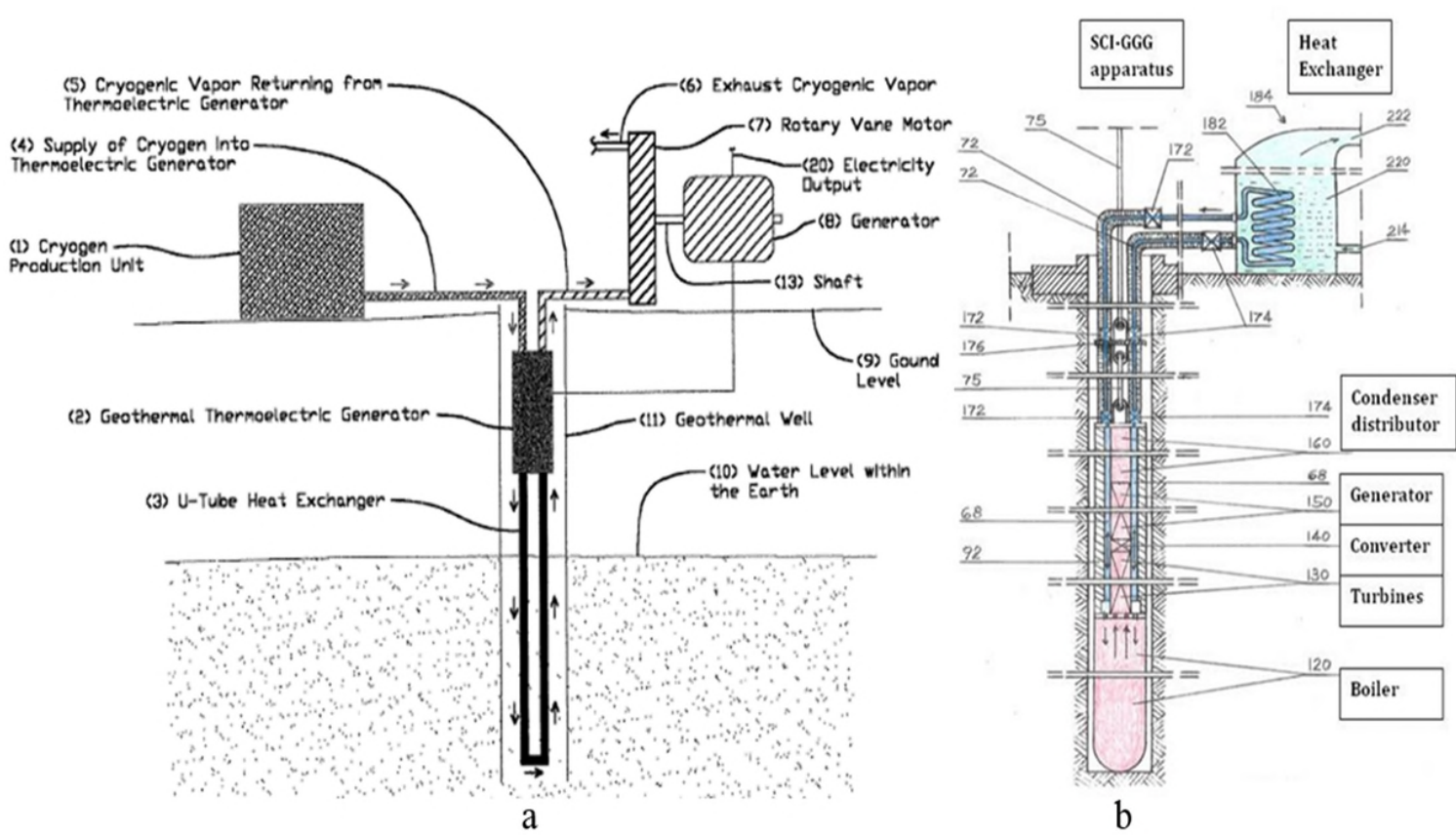

Fig. 15. Croygen thermoelectric generator in a deep geothermal well (a) [31] and Self Contained In-Ground Geothermal Generator (b) [32].

Lakic conceived and built several designs which are complementary to each other, including the Self Contained In-Ground Geothermal Generator (SCI-GGG) [32], which is shown in Fig. 15 b.

More recently, the Artificial Geyser concept has been proposed [33,34,35,36], as presented in Fig. 16. In this concept, water is injected from surface via the wellbore annulus space between production casing and tubing without pumping. After that, at a selected depth, the heated water enters the boiler via a flash evaporation valve that reduces its saturation point. Downstream of the valve, a downhole boiler allows heat exchange between the formation and the injected water. The steam exiting the boiler then flows back to surface up the tubing in the same well.

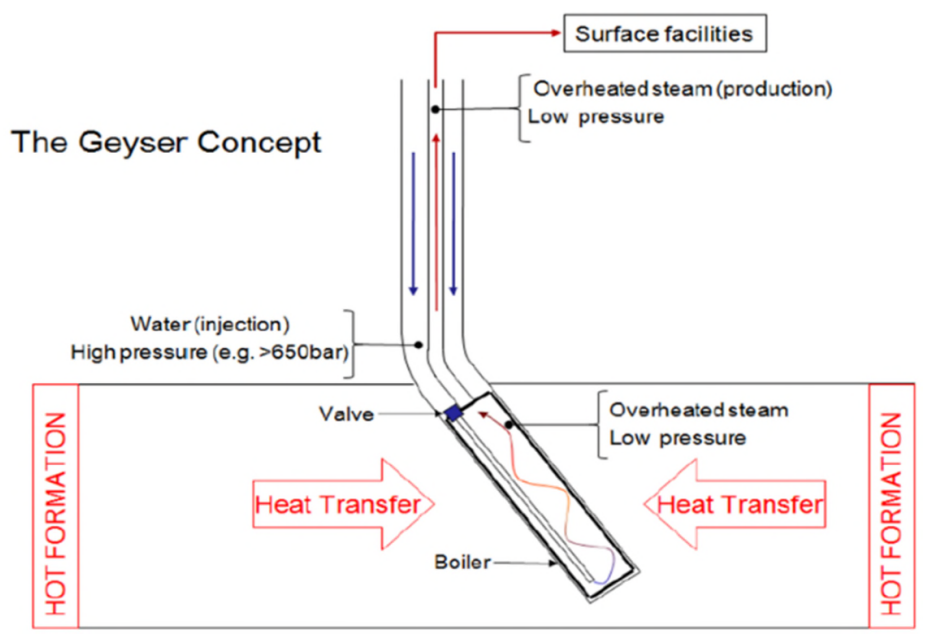

Fig. 16. The Artificial Geyser concept [36].

In his invention (US Patent No. 4912941), Büchi [37] presented another concept. As shown in Fig. 17 a, a vertical deep well is firstly drilled with a depth of 5000-10000 m. Then, by means of blasting or hydraulic fracturing, penetrating passages ( 7 in Fig. 17 a) are created from the bottom zone of the well into the rock outwardly. The softened rock at the bottom zone can be flushed out with chemicals after blasting. After that, the well would be re-drilled. In such a way, a borehole that has greater diameter bottom part and penetrating passages is created, which leads to larger heat exchange area. Afterwards, heat conducting 
materials ( $\mathrm{S}$ in Fig. 17 a) consisting of water, cement, siliceous gel and finely divided metal powder is injected to fill the passages, which is left in the well bottom to solidify. The casing ( 9 in Fig. 17 a) with sealed bottom is then placed in the borehole. In order to thermally bond the casing to the heat conducting substance, contact matrix (M in Fig. 17 a) is injected along the exterior face of the casing. This substance should contain main cement and/or siliceous gel, interspersed with metal powder or fibers. After this step, a pipe (11 in Fig. 17 a) with an open bottom is inserted. This pipe should be insulated to avoid heat exchange between injected and produced medium. In the end, a heat transmission medium (W in Fig. 17 a), such as water for convenience, is injected between casing 9 and pipe 11 . The water evaporates downhole and the steam or the mixture of water and steam is produced via the inner pipe 11. [37]
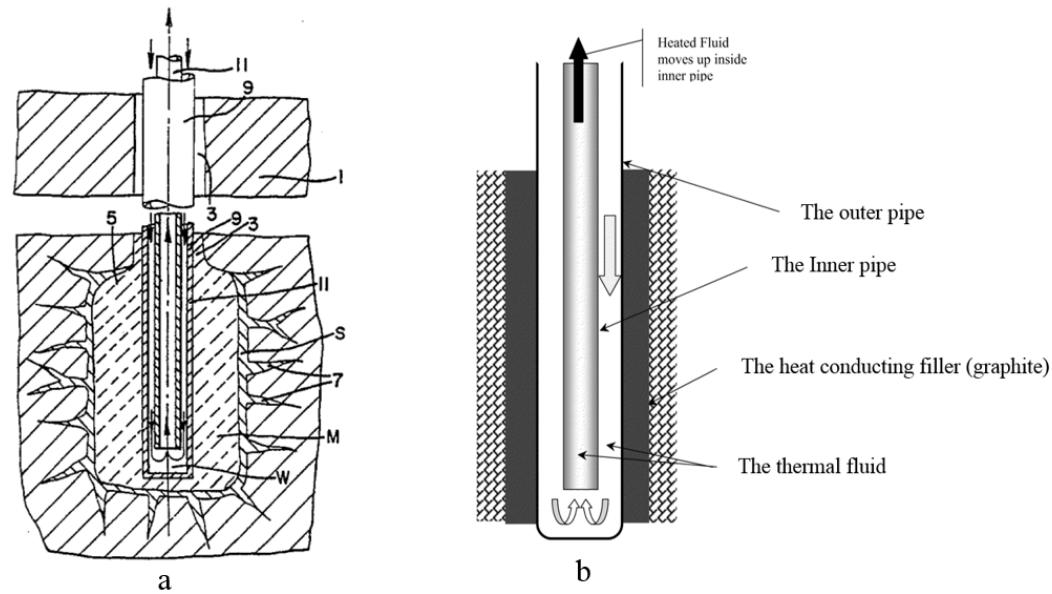

Fig. 17. The single well concept based on US patent 4912941 (a) [37] and single well closed loop system with the heat conducting filler of graphite (b) [38].

Hara [38] described another variation of single-well (closed loop) systems. In his concept, a well is drilled deep into the earth's crust until it reaches the desired depth and temperature zone. The system is comprised of casing pipes and concentrically production tubing placed inside (see Fig. 17 b). The space between the casing and borehole is to be filled with a filler, consisting mainly of graphite. The goal is to increase the heat exchange between hot formation and thermal fluids. Additionally, it is also suggested to use insulating cement above the targeted zone to prevent heated thermal fluids from losing heat.

\section{Single-well (closed loop) numerical model: BHE with conducting fillers}

The boreholes accommodate separate conduits for the down-going (cold) and up-going (warm/hot) fluids. It must be emphasized that these fluid streams should be thermally well insulated from each other in order to avoid heat exchange between them. The efficiency of the single-well (closed loop) systems presented above depends on the sustainability of the heat extraction rate vis-à-vis the thermal replenishment in the near wellbore. The latter largely depends on the thermal conductivity of the geological formations penetrated by the borehole, but also locally on the advective replenishment by flowing groundwater [22]. While solutions to enhance the heat exchange between the heat-carrying fluid and the ground in shallow BHE systems have been extensively presented in the literature [39], less is known regarding the improvement of downhole heat exchange characteristics in thermally-boosted, deep BHE systems. Following preliminary results [40], a numerical model was therefore built as part of this study to assess the bulk thermal potential associated with the deep BHE concept of Fig. 17 when extrapolated to the most challenging environment, which - for some regions in the world - may represent the only target for temperatures high enough to generate electrical power. The co-axial deep BHE model was constructed in FEFLOW 6.2 to simulate the circulation of single-phase water (no steam) in the settings presented by Hara [38]. The main purpose of this model effort was to determine whether exploitation methods suggested in past patents are technically feasible and if so, how much improvement they could provide in the process of heat extraction.

\subsection{Model description}

FEFLOW is a finite element simulation system for modelling 3D and 2D flow, mass, age and heat transport processes in groundwater and the vadose zone. The software has the capability of modelling BHEs using a 1D finite element approach. The modelling of BHEs in FEFLOW is based on previous work by Al-Khoury et al. [41,42], who first implemented 1D single and double U-pipe components in the setting of geothermal heating systems, and Eskilson and Claesson [43], who brought about 
an analytical solution based on local steady-state conditions and a given thermal equilibrium. FEFLOW gives the option of using either of the models, with Al-Khoury et al.'s best suited for short-term predictions, and Eskilson and Claessons' for longterm predictions.

A report from Bram et al. [44] was used in this study as the primary source of data to recreate settings representative of a very deep geothermal system. The report contains various data about the deep regional lithology and relevant rock properties (up to $9101 \mathrm{~m}$ ) of the KTB deep borehole project. In order to allow varying spatial discretization, the model was sub-divided into two polygons with a generated finite-element mesh. The 3D model consists of 20 layers, where each has an equal thickness of $400 \mathrm{~m}$ (see Fig. 18), indicating a total reservoir depth of $8000 \mathrm{~m}$. Overall, the model has 21 slices and the size of each slice is $1000 \mathrm{~m} * 1000 \mathrm{~m}$. The total number of elements is 49420 . Different rock types based on the actual database of the KTB deep borehole logs are located into the model at the relevant depths, including biotite, hornblende gneiss and amphibolite. The input properties of each rock type can be found in Table 1. The design details of the simulated BHE is presented in Table 2.

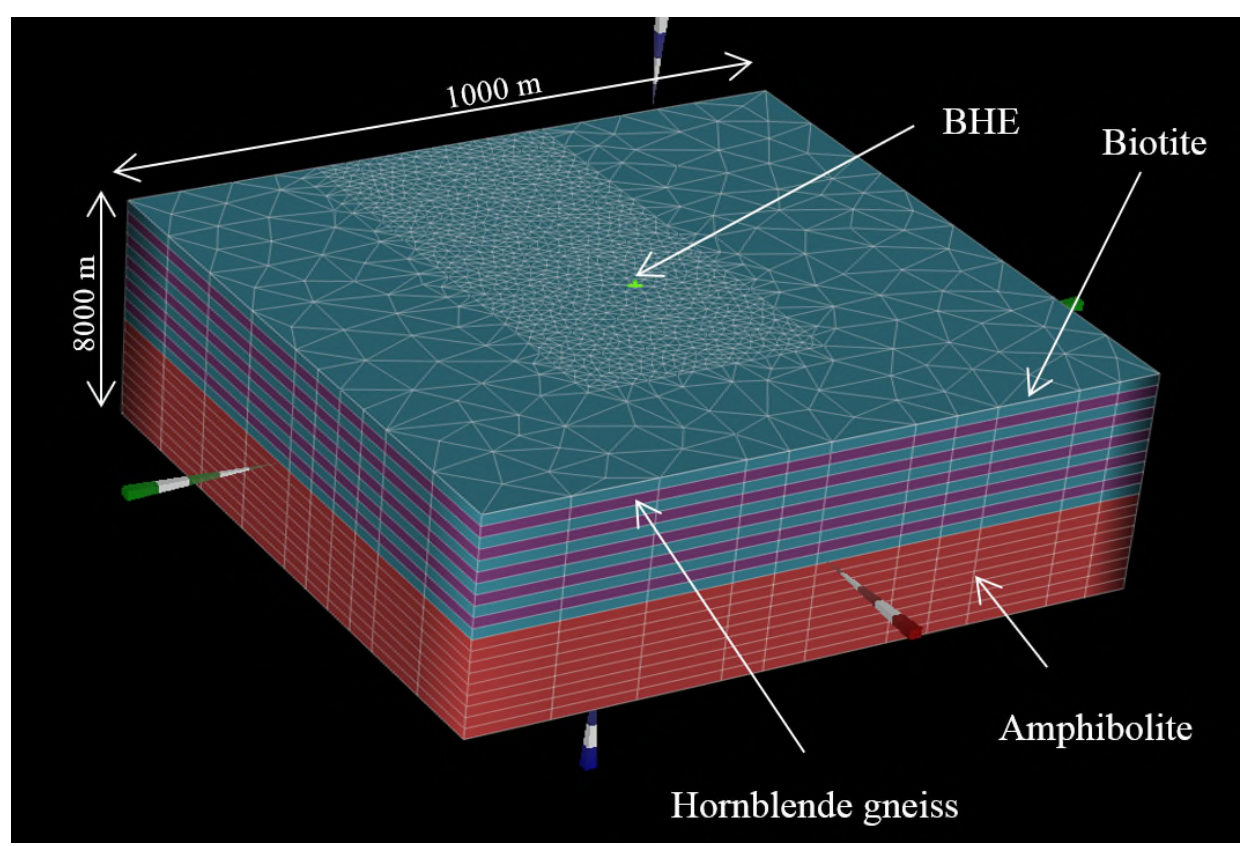

Fig. 18. 3D-View of the simulated reservoir with integrated lithology (after [45]).

Table 1. Rock Properties assigned to the model (after [45])

\begin{tabular}{|c|c|c|c|}
\hline Materials & Porosity (fraction) & $\begin{array}{c}\text { Thermal Conductivity } \\
{[\mathrm{J} / \mathrm{m} / \mathrm{s} / \mathrm{K}]}\end{array}$ & $\begin{array}{c}\text { Specific Heat Capacity } \\
{[\mathrm{MJ} / \mathbf{k g ~ K ]}}\end{array}$ \\
\hline Biotite & $0.17^{[46]}$ & $2.3^{[47]}$ & $2.89^{[49]}$ \\
\hline Hornblende & $0.04^{[46]}$ & $1.89^{[47]}$ & $2.52^{[49]}$ \\
\hline Amphibolite & $0.01^{[46]}$ & $3^{[48]}$ & $2.52^{[50]}$ \\
\hline
\end{tabular}

Table 2. Design details of BHE

\begin{tabular}{|l|c|}
\hline Property & Value \\
\hline BHE Geometry & Coaxial (annular inlet) \\
\hline Borehole Diameter & $0.3175 \mathrm{~m}$ \\
\hline Inlet Pipe Diameter & $0.2445 \mathrm{~m}$ \\
\hline Inlet Pipe Wall Thickness & $0.008941 \mathrm{~m}$ \\
\hline Outlet Pipe Diameter & $0.1016 \mathrm{~m}$ \\
\hline Outlet Pipe Wall Thickness & $0.00574 \mathrm{~m}$ \\
\hline Inlet Pipe Thermal Conductivity & $50 \mathrm{~J} / \mathrm{m} / \mathrm{s} / \mathrm{K}$ \\
\hline
\end{tabular}




\begin{tabular}{|l|c|}
\hline Outlet Pipe Thermal Conductivity & $0.01038 \mathrm{~J} / \mathrm{m} / \mathrm{s} / \mathrm{K}$ \\
\hline Grout Volume Thermal Conductivity & $1 \mathrm{~J} / \mathrm{m} / \mathrm{s} / \mathrm{K}$ \\
\hline
\end{tabular}

The bottom of the BHE was set to a depth of $7000 \mathrm{~m}$. The subsurface fluid was assumed to be water with a volumetric heat capacity of $4.184 \mathrm{MJ} /\left(\mathrm{m}^{3} \mathrm{~K}\right)$ and a thermal conductivity of $0.609 \mathrm{~J} / \mathrm{m} / \mathrm{s} / \mathrm{K}$ [51]. The saturated groundwater-flow option was chosen to simulate the underground heat transport, indicating a $100 \%$ water saturation. The hydraulic head in the entire subsurface block was defined as $0 \mathrm{~m}$, including the boundaries, to ensure no flow entry. The surface temperature was defined as $15{ }^{\circ} \mathrm{C}$, with a temperature gradient of $4{ }^{\circ} \mathrm{C} / 100 \mathrm{~m}$, leading to a bottom temperature of $330^{\circ} \mathrm{C}$. In addition, a water circulation rate of $604.8 \mathrm{~m}^{3} / \mathrm{d}$ was assumed.

The relevant parameters of the cells surrounding the BHE were modified to act as the heat conducting filler, based on the properties of graphite, which vary depending on its quality and on graphite flakes placement. For this study, the assumption was made of flakes successfully placed laterally and parallel to one another, which maximizes the thermal conductivity. The value of thermal conductivity of graphite flakes could vary between a maximum of $500 \mathrm{~W} /(\mathrm{mK})$ and a minimum of $140 \mathrm{~W} /(\mathrm{mK})$ [52]. In this study, the value of graphite conductivity was set to $300 \mathrm{~W} /(\mathrm{mK})$. In the model configuration, graphite filled the surrounding of the BHE from slice 12 to 18 , corresponding to a depth of $4400-7200 \mathrm{~m}$. The simulation time was set to $10 \mathrm{yrs}$.

\subsection{Results and Discussions}

In the model, the circulated water was injected from surface at the temperature of $15{ }^{\circ} \mathrm{C}$ (see Fig. 19 a) and was heated up while descending through the annular space of the BHE. After that, the fluids were produced to surface within the insulated tubing. The corresponding annular, tubular and grout temperature profiles at the end of the simulation time are shown in Fig. 20. The main concern that triggered this study was that the reservoir temperature could fall rapidly due to the cooling effect of the water circulation within the BHE. In Fig. 19 b, the BHE outlet temperature is seem to be decreasing gradually during the entire production period. However, from the beginning until the final 10yrs of circulation, the reservoir cooling is relatively slow, indicating that the formation is actively recharging heat upon its extraction. As presented in Fig. 20, even in the final days of the simulation, the grout temperature at the bottom of the well remains higher than $160{ }^{\circ} \mathrm{C}$ and the temperature of the produced water at surface has a temperature higher than $110^{\circ} \mathrm{C}$. This arrival temperature of the circulation fluids is sufficient to generate electricity with modern Organic Rankine Cycle (ORC) power plants [53]. In addition, the observed grout temperature profile in Fig. 20 reflected the heat capacity of each different rock layer, suggesting a realistic response of the model to the assumed geology.

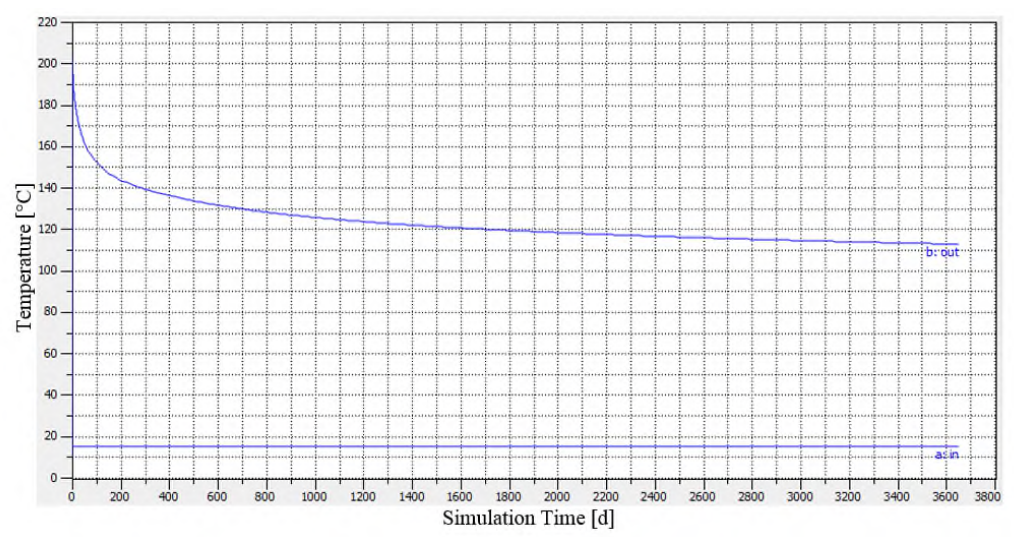

Fig. 19. BHE inlet and outlet temperatures over the simulation time of $10 \mathrm{yrs}$. 


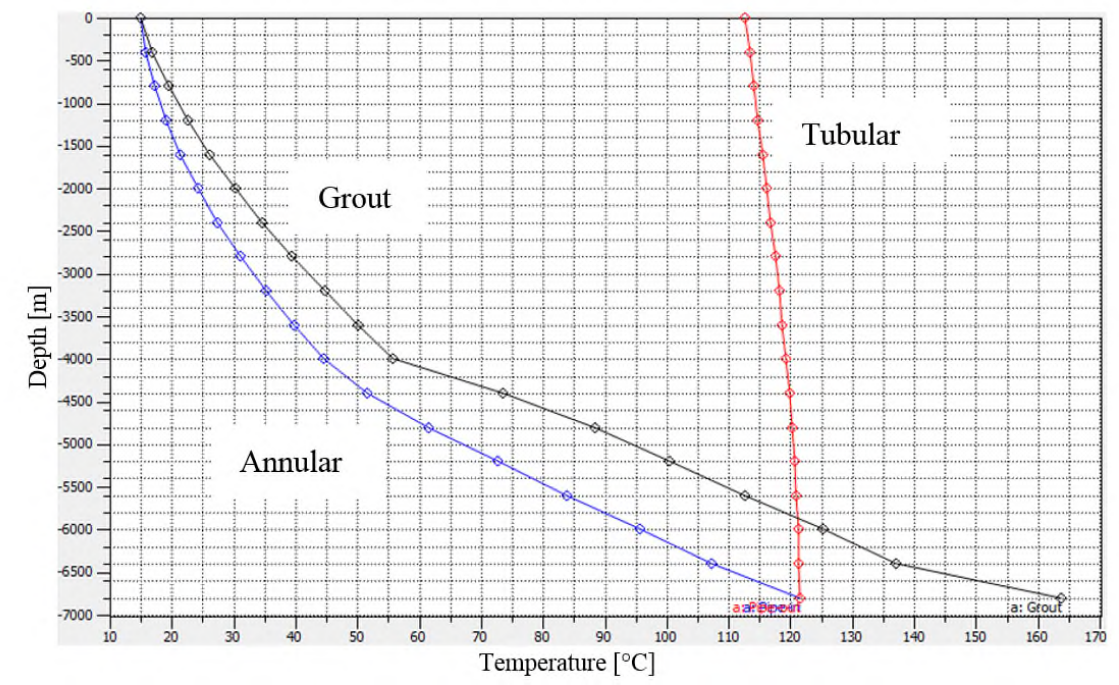

Fig. 20. Annular, tubular and grout temperatures profiles after the simulation time of 10yrs (after [45]).

Daily heat production of the simulated BHE system is displayed in Fig. 21. Note that, the minus signs on the vertical axis are representing the geothermal energy extracted from the system. As can be seen, the geothermal energy produced per day slowly decreases during the simulation period. At the end of the simulation, the produced power of the BHE is still higher than $3 \mathrm{MW}$, suggesting a significant capacity potential.

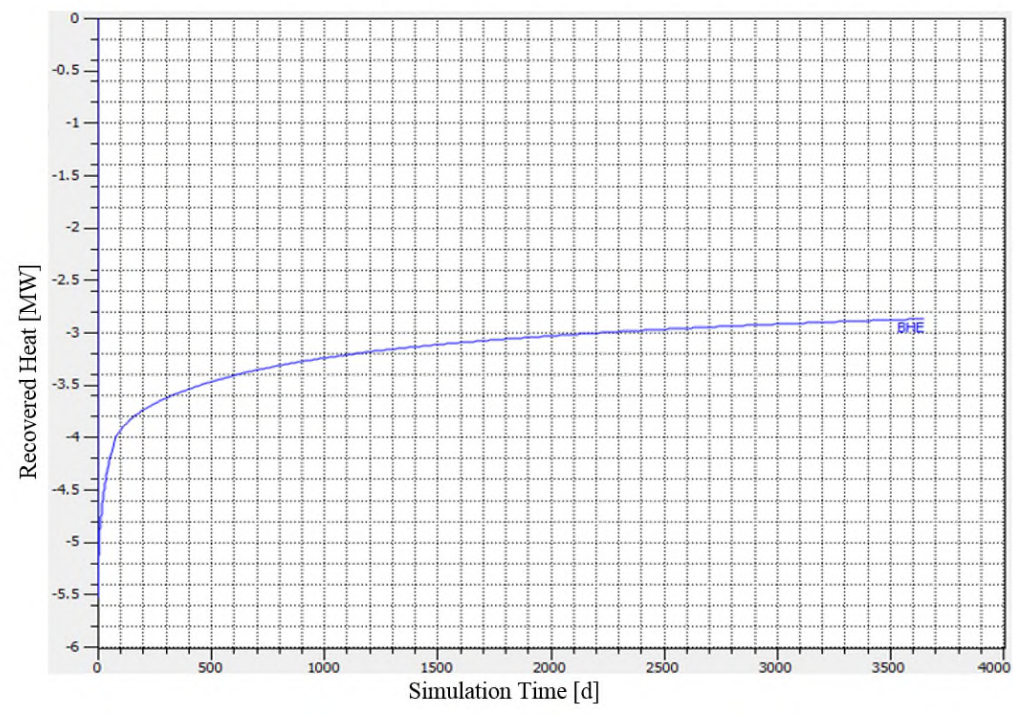

Fig. 21. Daily recovered heat from geothermal reservoir by the simulated BHE (after [45]); note that, the recovered heat is presented in negative values as the heat is extracted from the simulated system.

\section{Conclusions and Recommendations}

A comprehensive, critical assessment of conventional and unconventional deep geothermal well designs was presented, covering injection-production well doublets, U-tube single wells, open-loop single wells and closed-loop single wells. The goal of the evaluation was to identify more sustainable development options as an alternative to EGS, to limit site-specific risks and to avoid reservoir stimulation and the associated induced seismicity. The BHE concept, originally developed for shallow geothermal applications, can - in principle - be applied to greater depths. However, only a few deep installations have been implemented to date, but within $2,500 \mathrm{~m}$ only, with mixed success and not with the aim of generating electrical power. The latter has been the focus of published patents proposing modifications of the original BHE principle, including enlargement of the downhole contact area between formation and well, and the addition of fillers to enhance the heat transfer between the near- 
wellbore region and the fluid circulating in the well. The majority of these proposed BHE modifications for deep applications tend to lack thorough studies to predict their thermal sustainability. In order to develop a more rigorous understanding of the feasibility of these concepts, numerical simulations of a BHE design with heat conductive fillers were carried out as part of the work presented here. Encouraging results were obtained, suggesting that there is a need for further research into engineered, closed-loop single-well solutions to untap the great potential of deep geothermal resources worldwide. These could initially be applied to particularly favorable candidate locations, e.g. shallower (but high temperature) settings, as encountered in Iceland, for example, and/or where abandoned or "dry" geothermal or hydrocarbon wells can be re-used, so as to minimize operational costs while gaining valuable implementation lessons.

\section{Acknowledgement}

We would like to present our gratitude to DHI for the FEFLOW academic agreement during the course of the study.

\section{References}

[1] BP Global, BP Statistical Review of World Energy June 2016, http://www.bp.com/content/dam/bp/pdf/energyeconomics/statistical-review-2016/bp-statistical-review-of-world-energy-2016-full-report.pdf, 2017 [accessed 21.04.2017]

[2] BP Global, BP Statistical Review of World Energy June 2017, https:/www.bp.com/content/dam/bp/en/corporate/pdf/energy-economics/statistical-review-2017/bp-statistical-review-ofworld-energy-2017-full-report.pdf [accessed 10.08.2017]

[3] International Energy Agency, Renewables Information: Overview, 2017 edition.

[4] REN21, Renewables 2016 Global Status Report (Paris: REN21 Secretariat), 2016. ISBN 978-3-9818107-0-7

[5] International Energy Agency, Energy Technology Perspectives 2017 Excerpt Informing Energy Sector Transformations, June 2017.

[6] Lu, S.M., A global review of enhanced geothermal system (EGS), Renewable and Sustainable Energy Reviews, 2017, ISSN 1364-0321, http://dx.doi.org/10.1016/j.rser.2017.06.097.

[7] Chamorro, C.R., García-Cuesta, J.L., Mondéjar, M.E. and Pérez-Madrazo, A., Enhanced geothermal systems in Europe: An estimation and comparison of the technical and sustainable potentials, Energy, Volume 65, 2014, Pages 250-263, ISSN 0360-5442, http://dx.doi.org/10.1016/j.energy.2013.11.078.

[8] Olasolo, P., Juárez, M.C., Morales, M.P., D’Amico, S. and Liarte, I.A., Enhanced geothermal systems (EGS): A review, Renewable and Sustainable Energy Reviews, Volume 56, 2016, Pages 133-144, ISSN 1364-0321, http://dx.doi.org/10.1016/j.rser.2015.11.031.

[9] Grigoli, F., Cesca, S., Rinaldi, A.P., Manconi, A., López-Comino, J.A., Clinton, J.F., Westaway, R., Cauzzi, C., Dahm, T. and Wiemer, S., The November $2017 \mathrm{Mw} 5.5$ Pohang earthquake: A possible case of induced seismicity in South Korea, Science, 2018, http://dx.doi.org/10.1126/science.aat2010.

[10] Breede, K., Dzebisashvili, K. and Falcone, G., Overcoming challenges in the classification of deep geothermal potential, Geoth Energ Sci 2015; 3: 19-39. https://dx.doi.org/10.5194/gtes-3-19-2015.

[11] Breede, K., Dzebisashvili, K., Liu, X. and Falcone, G., A Systematic Review of Enhanced (or Engineered) Geothermal Systems: Past, Present and Future, Geothermal Energy 2013; 1:4, https://dx.doi.org/10.1186/2195-9706-1-4.

[12] Buscheck, T., Bielicki, J., Edmunds, T., Hao Y., Sun Y., Randolph J. and Saar M. Multifluid geo-energy systems: Using geologic $\mathrm{CO}_{2}$ storage for geothermal energy production and grid-scale energy storage in sedimentary basins, Geosphere 2016; 12/3: 1-19. https://dx.doi.org/10.1130/GES01207.1

[13] Potter, R., Robinson, E. and Smith, M., Method of extracting heat from dry geothermal reservoirs, US Patent No. 3786858 ; 1974. [accessed 24.04.2017] 
[14] Tester, JW., Anderson, BJ., Batchelor, AS., Blackwell, DD., DiPippo, R., Drake, EM. Garnish, J., Livesay, B., Moore, MC., Nichols, K., Petty, S., Toksöz, MN. and Veatch, RW Jr., The Future of geothermal energy - impact of enhanced geothermal systems on the United States in the 21st Century, US Department of Energy, Washington, D.C. $2006 \mathrm{a} ; 1-11$.

[15] Heidinger, P., Integral modelling and financial impact of the geothermal situation and power plant at Soultz-sous-Forêts, Comptes Rendus Geoscience, 342 (2010), pp. 626-635, 10.1016/j.crte.2009.10.010

[16] Shiozawa, S. and McClure, M., EGS Designs with Horizontal Wells, Multiple Stages, and Proppant, Thirty-Ninth Workshop on Geothermal Reservoir Engineering Stanford University, Stanford, California, February 24-26, 2014 SGP-TR202

[17] Isaakidis, I., Isaakidis high temperature engineered geothermal systems, US Patent No. 2010206101 B2; 2012. [accessed 25.04.2017]

[18] GreenFire Energy, GreenFire Demonstration Project,
https://geothermal.org/pdfs/Coso_Demonstration_March_2017.pdf, 2017 [accessed 25.04.2017]

[19] Tischner, T., Evers, H., Hauswirth, H., Jatho, R., Kosinowski, M. and Sulzbacher, H., New Concepts for Extracting Geothermal Energy from One Well: The GeneSys-Project, World Geothermal Congress 2010.

[20] Gedzius, I. and Teodoriu, C., Innovative Erschliesungskonzepte für Hot-Dry-Rock-Projekte im Norddeutschen Becken. DGMK/ÖGEW-Frühjahrstagung 2011, Fachbereich Ausführung und Gewinnung.

[21] Gaucher, E., Schoenball, M., Heidbach, O., Zang, A., Fokker, P.A., van Wees, J.D. and Kohl, T., Induced seismicity in geothermal reservoirs: A review of forecasting approaches, Renewable and Sustainable Energy Reviews, Volume 52, December 2015, Pages 1473-1490, ISSN 1364-0321, https://doi.org/10.1016/j.rser.2015.08.026.

[22] Rybach, L. and Hopkirk, R., Shallow and deep borehole heat exchangers - achievements and prospects. Proceedings World Geothermal Congress 1995.

[23] Eugster, W. and Füglister, H., Tiefe Erdwärmesonde Weggis - Messkampagne zur Dokumentierung der neuen Einflüsse beim Ausbau der Abnehmerleistung. http://mobil.hochschulebochum.de/fileadmin/media/geothermiezentrum/Downloads/Tiefe_Geothermie/Tiefe-Erdwaermesonde-Weggis.pdf, 2003. [accessed 25.04.2017]

[24] Kohl, T., Brenni, R. and Eugster W., System performance of a deep borehole heat exchanger, Geothermics, Volume 31, Issue 6, 2002, Pages 687-708, ISSN 0375-6505, http://dx.doi.org/10.1016/S0375-6505(02)00031-7.

[25] Kohl, T., Salton, M. and Rybach L., Data Analysis of the Deep Borehole Heat Exchanger Plant Weissbad (Switzerland), Proceedings World Geothermal Congress 2010.

[26] Kohl, T. and Rybach, L., Projekt Statistik Geothermische Nutzung der Schweiz für die Jahre 2002 und 2003. http://www.ub.unibas.ch/digi/a125/sachdok/2009/IBB 1 004629691.pdf, 2004. [accessed 25.04.2017]

[27] Aachener-nachrichten. Erdwärme für das SuperC: Der Leuchtturm der Forschung. http://www.aachenerzeitung.de/lokales/region/erdwaerme-fuer-das-superc-der-leuchtturm-der-forschung-1.387215, 2001. [accessed 25.04.2017]

[28] Dijkshoorn, L., Speer, S. and Pechnig, R., Measurements and Design Calculations for a Deep Coaxial Borehole Heat Exchanger in Aachen, Germany International Journal of Geophysics, Volume 2013, Article ID 916541, 14 pages,http://dx.doi.org/10.1155/2013/916541

[29] Collins, M.A. and Law, R., The Development and Deployment of Deep Geothermal Single Well (DGSW) Technology in the United Kingdom, European Geologist Journal 43, 2017.

[30] Van Huisen, A.T. Geothermal exchange system. US Patent No. 3470943 A; 1969. [accessed 25.04.2017] 
[31] Hunt, R.D., Method of enhanced heat extraction from a geothermal heat source for the production of electricity thermoelectrically and mechanically via the high-pressure injection of a cryogen into a u-tube or open tube heat exchanger within a geothermal heat source. US Patent No. 20030010652 A1; 2003. [accessed 25.04.2017]

[32] Lakic, N., Self-contained in-ground geothermal generator and heat exchanger with in-line pump. US Patent No. 20130055714 A1; 2013. [accessed 25.04.2017]

[33] Bierenriede, L., Feasibility Study of an Extremely Deep Geothermal Well in Switzerland. Master Thesis. Clausthal University of Technology; 2011.

[34] Heller, K. and Teodoriu, C., Geothermische Energiegewinung, Patent application number 21193 filed on 05022013 to the Swiss federal institute of intellectual property. (2013)

[35] Heller, K., Teodoriu, C. and Falcone, G., A New Deep Geothermal Concept Based on the Geyser Principle, Proceedings Thirty-Ninth Workshop on Geothermal Reservoir Engineering 2014.

[36] Teodoriu, C., Falcone, G. and Alrutz Barcelos J.G., The Artificial Geyser Concept - New Insights, Proceedings Fourtieth Workshop on Geothermal Reservoir Engineering 2015.

[37] Büchi, H. F., Method and apparatus for extracting and utilizing geothermal energy, US Patent No. 4912941 A; 1990. [accessed 26.04.2017]

[38] Hara, H., Geothermal Well Using Graphite As Solid Conductor, US Patent No. 20110232858 A1; 2011. [accessed 27.04.2017]

[39] Faizal, M., Bouazza, A. and Singh, R.M., Heat transfer enhancement of geothermal energy piles, Renewable and Sustainable Energy Reviews, Volume 57, 2016, Pages 16-33, ISSN 1364-0321, http://dx.doi.org/10.1016/j.rser.2015.12.065.

[40] Okech, R. R., Liu, X., Falcone, G., \& Teodoriu, C., Unconventional Completion Design for Deep Geothermal Wells. Society of Petroleum Engineers. (2015, November 18). doi:10.2118/177228-MS

[41] Al-Khoury, R., Bonnier, P.G. and Brinkgreve R.B.J., Efficient finite element formulation for geothermal heating systems. Part I: Steady state. International Journal for Numerical Methods in Engineering 2005; 63(7): 988 - 1013. https://dx.doi.org/10.1002/nme.1313.

[42] Al-Khoury, R. and Bonnier, P.G., Efficient finite element formulation for geothermal heating systems, Part II: Transient, International Journal for Numerical Methods in Engineering 2006; 67(5): 725 - 745. https://dx.doi.org/10.1002/nme.1662.

[43] Eskilson, P. and Claesson, J., Simulation Model for thermally interacting heat extraction boreholes. Numerical Heat Transfer 1988; 13: 149-165. http://dx.doi.org/10.1080/10407788808913609.

[44] Bram, K., Draxler, J., Hirschmann, G. and Zoth, G., The KTB Borehole: Germany's Superdeep Telescope into the Earth's Crust. https://www.slb.com/ /media/Files/resources/oilfield_review/ors95/jan95/composite.pdf, 1995 [accessed 26.04.2017]

[45] Seyidov. F., Investigation of the Feasibility and Efficiency of Deep Borehole Heat Exchangers, Master Thesis. Clausthal University of Technology; 2016.

[46] Emmermann, R. and Lauterjung, J., The German Continental Deep Drilling Program KTB: Overview and major results. Journal of geophysical research 1997; 102 (B8): 18,179-18,201.

[47] Somerton W., Thermal properties and temperature-related behavior of rock/fluid systems. Volume 37, Elsevier Science; 1992.

[48] Robertson E.R., Thermal Properties Of Rocks. US Department of Interior Geological Survey, http://pubs.usgs.gov/of/1988/0441/report.pdf, 1988 [accessed 26.04.2017]

[49] Engineering ToolBox. Solids - Specific Heats. http://www.engineeringtoolbox.com/specific-heat-solids-d_154.html, 2017a [accessed 26.04.2017] 
[50] Eppelbaum, L., Kutasov, I. and Pilchin, A., Thermal Properties of Rocks and Density of Fluids; 2014, p. 99-149.

[51] Engineering ToolBox. Common fluids and their thermal conductivity. http://www.engineeringtoolbox.com/thermalconductivity-liquids-d_1260.html, 2017b [accessed 26.04.2017]

[52] Smalc, M., Shives, G., Chen, G., Guggari, S., Norley, J. and Reynolds, A., Thermal Performance Of Natural Graphite Heat Spreaders. Proceedings of IPACK2005.

[53] Liu, X., Falcone, G. and Alimonti, C., Harnessing the Heat from a Mature Oil Field. European Geothermal Congress 2013. 